I Princeton University, New Jersey, NJ, United States of America

jorge.acuna@usp.br

Mauricio Acuña'

\title{
THE BERIMBAU'S SOCIAL GINGA: NOTES TOWARDS A COMPREHENSION OF AGENCY IN CAPOEIRA
}

Technology is enchanting because it is enchanted, because
it is the outcome of some process of barely comprehensible
virtuosity, that exemplifies an ideal of magical
efficacy that people struggle to realize in other domains.

(Nicholas Thomas, 1998: ViII).

\section{INTRODUCTION}

The following article discusses how a musical instrument, the berimbau, acquired a particular range of possibilities as capoeira expanded and transformed over the course of the twentieth century, while simultaneously considering some of the key moments in the configuration of the latter. I argue that we need to recognize the specific types of agency possessed by the berimbau as an instrument that simultaneously enables an 'ancestral memory' and feeds the national imagination. This agency concerns the realm of song and music, but also the disciplinary control of the body. I begin my exploration of the topic by turning first to recent history.

Following the famous journey of Mestre Pastinha to Africa in I966 - immortalized by Caetano Veloso in his song 'Triste Bahia'I (Sad Bahia) - it would still be a few decades before capoeira finally reached the shores of Angola, one of the mythical birthplaces of the practice. Ironically, as the song pointed out, "Pastinha já foi a África, pra mostrar capoeira do Brasil" [Pastinha has already gone to Africa, to demonstrate Brazilian capoeira]. Today, as part of the globalization of capoeira, ${ }^{2}$ we can observe the arrival of Brazilian capoeiristas to promote the practice in Angola, a country central to the debate among researchers and practitioners about the origin of this cultural expression. Prominent historical sources have emphasized the relevance of Angolan Bantu 
populations in the creation and promotion of capoeira in Brazil since the beginning of the twentieth century (Querino, I922; Carneiro, I937; Rego, I968).

In the I96os, the Angolan painter Albano Neves Souza ${ }^{3}$ added fuel to this hypothesis when he highlighted the similarity between capoeira ${ }^{4}$ and N'Golo - a kind of initiation ritual traditional to the southern region of the country (Rohrig, 2005: 49). On the Brazilian side of the Atlantic, it is worth remembering that 'Angola' is one of the names given to a variety of capoeira that began to become consolidated in the r930s, emphasizing the continuity between the practice and its ancestral imaginaries.

The current presence of capoeira groups in one of the nations that formed part of the ancestral territory of Bantu populations suggests a kind of 'return to the source,' reinforcing the Afrocentric interpretations already prevalent in other expressions, including various religious practices (Dantas, I988: 48). In the case of the Brazilian capoeiristas, the berimbau seems to have become the most effective intermediary agent in the promotion of a dialogue with Angolan practitioners, recognizing the ancient popularity of the instrument. However, a number of dissonances in the use of the instrument by capoeiristas can also be noted, and these indeed prove significant for the analysis undertaken in this text.

Although the berimbau used in capoeira is similar to the instrument traditionally played in Angola and known to ethnomusicologists as a bowstring monochord (Biancardi, 2006) or the African musical bow (Shaffer, I977), there is no concrete evidence of its association with any practice even vaguely reminiscent of capoeira, as in the case of N'Golo. ${ }^{5}$

In twenty-first century Angola, use of the berimbau seems to have become well established, exemplified by the likes of Mestre Kamosso, a virtuoso player who performs in public spaces like local markets. In 2013 he received official recognition from the local government of the importance of his contribution to Angolan culture (Silva \& Albano, 2013: n.p.).

A video distributed by capoeiristas on social media ${ }^{6}$ draws attention to Kamosso's precarious situation, however. The film's narrative tells us that this once popular figure has now been abandoned, echoing other examples of neglect in the collective memory of capoeiristas, such as the cases of Mestre Pastinha and Mestre Bimba, two of the most important exponents of capoeira in twentieth century Brazil (Acuña, 2010: 92).

Although an important phenomenon in itself, my immediate concern is not to discuss the 'abandonment effect' felt among capoeiristas but to highlight the significance of the appeal for support and solidarity that followed the video's distribution on YouTube. This took the form of a collective action to paint Kamosso's house, ending with a cheerful capoeira roda, a very familiar sight for people in Brazil today and in the more than I50 countries where the practice exists. $^{7}$ 
The eleven-minute film presents a conversation between Kamosso and the capoeiristas. This is followed by images of his house being painted and a capoeira roda being performed when the work was finished, showing practitioners dancing together with children from the local neighbourhood. When the performance begins and Kamosso finds himself sitting among the capoeiristas, playing his berimbau, a certain disconnection between the artist and the capoeiristas is evident. The claps are out of synch with the rhythm set by the instrument and the fact that two people are dancing in front of the berimbau seems to cause the player some discomfort, eventually leading him to leave the circle.

This brief account of 'berimbau dissonance' in Angola helps illustrate the important role played by the object today in eliciting new relationships, as well as in revitalizing old imaginings of capoeira's origin. So how are the berimbau's potentialities and its specific modes of agency consolidated within the capoeira universe? And what kinds of negotiations are enabled by the in strument?

Although somewhat ample in scope, these are the main questions I wish to explore in this text, framed by two moments in the berimbau's consolidation as a specific strategy adopted by capoeiristas in twentieth-century Brazil. The first moment, less studied but very audible, sings of the time of a 'poisonous' capoeira, more violent and accustomed to the clashes and conflicts of the first decades of the century, especially the ig2os. The second moment became fully visible in the rg6os when the 'disciplinary' uses of the berimbau were incorporated into capoeira's internal economy, along with its connections to important new trends in Brazilian music such as Bossa Nova and Tropicália.

In between these two moments, I look to emphasize the berimbau's centrality within its relational environment as an object that mediates social agency, as proposed by Alfred Gell (I998: 7) in his analysis of art works. Although the classification of the berimbau as an 'art object' may appear questionable, Gell's endeavour to formulate the grounds for an anthropological theory of art is ripe for exploration. One of the basic assumptions of his proposal is that 'agency' can be understood as an attribute of people and things "who/which are seen as initiating causal sequences of particular type, that is, events caused by acts of mind or will or intention, rather the mere concatenation of physical events. An agent is one who 'causes events to happen' in their vicinity" (Gell, I998: I6).

My proposal, therefore, is that it may be interesting to explore the berimbau with this definition in mind, observing the relationships that it establishes in its surroundings, and how it assumes the place of both the agent who performs the action and the patient who receives it.

Given the importance of the berimbau in capoeira music, ${ }^{8}$ I argue that the instrument plays a key role in the efforts made by intellectuals and artists 
to individualize their African origins and expand the concept of a miscegenated and cordial identity (Acuña, 2010). At the same time, it is well-known that music and song have become increasingly important for capoeiristas as a means of exerting control over the practice, limiting the violence that characterized capoeira in the I930s, and asserting the master's authority in the disputes to recruit students and appeal to tourists in a developing capoeira market.

In this case, acquiring authority is based on the capoeirista learning how to play the berimbau and sing, as well as using the instrument as a source of explanation about capoeira or even to publicize the practice in the academies, and the strategic management of bodies that fight, play and dance. In this sense I suggest that the acquisition of authority configures a discourse of power-knowledge in a swinging or gingada city (cidade gingada). ${ }^{9}$

From the viewpoint of the practices instituted by capoeiristas since the I930s, the increasing relevance of music and songs seems to be inversely proportional to the declining intensity of the violence involved in the practice. In terms of the effect on intellectuals and artists (not only from Bahia), meanwhile, the music and songs accompanying Bahian capoeira have fostered a kind of sensitivity that defines itself through ambivalence, converging with a wider discourse on national identity. ${ }^{\text {Io }}$ As I discuss below, ambivalence is conceived here as the quality of possessing two values, similar to the concept of the 'hybrid' formulated by Homi Bhabha (2007: 50).

This ambivalence has both synchronic and diachronic dimensions. First the narratives that envisage capoeira as a martial art, disguised in the form of a dance or game, and second as a dance that turned into a form of combat or a game, both ideas co-existing at various times (Acuña, 20I0: I59; Assunção, I995: I I3).

Another projection of ambivalence stimulated by the berimbau involves its perceived dilution of social hierarchies: a horizontal dimension of an 'imagined community' in which a broad sense of 'companionship' overlaps the divisions of colour, race, class, gender and so on (Anderson, I983: 25-6) in the name of the cultural power structure of the nation (Hall, 2003: 59). After the I930s, the presence of music and songs played an important role in turning Bahian capoeira into a national practice par excellence, again foregrounding its ambivalence. The songs and music asserted an art form distant from the marginalized position occupied by the practice until the First Republic (I889I930), yet still resonating, like a sounding board, with the same sense of marginalization. 


\section{THE POISONS OF CAPOEIRA: THE PAIN AND JOY OF THE BERIMBAU}

Esse gunga é meu/Eu não dou a ninguém/Esse gunga é meu/ Foi meu pai qui me deu/ Esse gunga é meu/ Eu não dô a ninguém [This gunga is mine/I don't give it to anyone/ This gunga is mine/My father gave it to me...]

(Capoeira song)

Though we know little about when the berimbau ceased to be an instrument associated with the solicitation of alms or trade and became a central component of capoeira music, some evidence suggests that this change took place in Bahia, possibly in the early twentieth century (Assunção, 2005: I Io). Manuel Querino in his book A Bahia de Outrora (I922) appears to have been the first author to observe such a practice controlled by chords, albeit attaching little significance to the fact. From the perspective of the 'lettered city' (Rama, I998), it was only from I936 and the work of folklorist and ethnologist Édison Carneiro that capoeira and its chords began to be described and heard in newspapers, books and meetings, including the Second Afro-Brazilian Congress, held in I937, which brought several capoeiristas to perform at Itapagipe Regatas Club as part of its program of activities (Acuña, 20IO: IOI).

After this period, Bahian capoeira increasingly imposed itself as the paradigm of national capoeira, lauded by the Brazilian Folkloric Movement and its network of 'provincial intellectuals,' institutionally organized into state-level commissions and the National Council of Folklore and Popular Culture, even becoming a topic in journal publications and large folklore meetings (Vilhena, I997).

For the 'gingada city' in the decades prior to I930, in both Bahia and Rio de Janeiro and in other urban locations, moments of intense repression of any practice associated with black populations are well-documented. For the elites and their modernization projects, it was imperative that the new Republic 'deAfricanize' public space (Dias, 2006: 26; Albuquerque, I999: 24). The effects of this policy were specifically felt by capoeira following the I 890 Penal Code, which outlawed the practice.

Persecution of capoeiristas and their diverse responses have been carefully studied in the case of a number of Brazilian cities. In Salvador, Josivaldo Pires de Oliveira presents important data on the regular presence of capoeiristas - called capadócios [brutes] and valentões [yobs] - in police diaries, for example, as well as tracing the connections between official documents and a collective memory present in several capoeira songs, which in many cases functioned as chronicles of the repression experienced over the years (Oliveira, 2004: 86).

Referring to this period from the first half of the twentieth century, Mestre Noronha (Daniel Coutinho), ${ }^{\text {II }}$ participant of one of the capoeira rodas in Salvador, provides important testimony on the dual function of the berimbau. Assuming a professional tone, he states: 
My dear capoeiristas and gym instructors, pay close attention: the berimbau is an instrument that leads the capoeira roda... Instructors, this instrument called the berimbau is the capoeirista's weapon; when necessary the means to defend himself in a fight is in his hands...not every capoeirista knows that the berimbau is a weapon... the wooden bow is a bludgeon to protect and to beat...the stick can perforate and defend him from enemies too... this is the advice of the old masters who know how to get into a fight and get out of one (Coutinho, 1993: 29).12

Despite raising a few questions concerning its status as a documentary record - a manuscript written by someone relatively unfamiliar with the written word and published only in the I99os - Noronha's discourse offers valuable rare testimony apropos the twin functions of the berimbau: leading the capoeira roda and serving as a defensive weapon against enemies. We know that the first function was being maintained and enhanced at the time when he left his account. The same, however, does not apply to the second.

The tone with which Mestre Noronha addresses the "capoeiristas and gym instructors," looking to teach them something that only the 'old masters' knew, also provides an insight into the value and recognition of an experience that no longer exists, an experience that explains the distinction between the I970 capoeiristas - the time when Noronha was writing - and earlier periods such as the first decades of the twentieth century. ${ }^{13}$ This distinction, which assumes a generational quality, takes as its touchstone the capoeirista's knowledge of the berimbau's virtues.

The experience narrated by Noronha refers to a time of violence involving capoeiristas, police officers, sailors, and political authorities, in which the importance of the dual function of the berimbau would be as important as the handling of a $\mathrm{knife}^{\mathrm{I} 4}$ to be able to enter and get out of a barulho - literally a 'noise,' slang here for a fight. ${ }^{15}$ This is the period which ethnologist Carneiro would qualify as 'poisonous capoeira' when he explained the practice to Ruth Landes in 1938, later published by herself in The City of Women (2002: 138).

Another testimony, rather enigmatic, was left by Mestre Pastinha in his Ig6os manuscripts: "What use has the berimbau? It is not only used to coordinate the action. And why is the berimbau, at the critical moment, dangerous? It is dangerous in the hands of someone who knows how to handle the berimbau, or something similar" (I997: 53). ${ }^{16}$

In the narratives recorded on an LP released during this same period, Mestre Pastinha gives a clearer idea of what this 'handling' would be, contrasting the berimbau's functions in an affective form: "berimbau is music, an instrument...it's also an offensive weapon. When everyone is happy, it's an instrument, we use it as instrument, and at a moment of duress, it transforms from an instrument into a scythe" (Pastinha, I969: track 3). ${ }^{17}$

He also describes his personal experience handling the instrument to turn it into a weapon, "I tell you, in my day I used to have a little curved blade the size of a key, and the blade had a slot and a ring to fit into the wooden 
bow....then, when the time came, I would dismantle the berimbau, attach the blade and it was ready to use..." (Pastinha, I969: track I). ${ }^{\text {18 }}$

The main opponents, according to the master, were the police officers who would constantly persecute them and try to repress the practice. ${ }^{19} \mathrm{Al}-$ though Pastinha justified police repression as a response to what he called capoeiristas desordeiros, ${ }^{20}$ disordered capoeiristas, he added that capoeiristas were often provoked by government forces: "if we were playing capoeira with a berimbau, they would try to rip it out of our hands to break it, and then things turned nasty, because many capoeiristas didn't want to lose their instrument, so we had to fight..." (Pastinha, I969: track 3). ${ }^{21}$

The centrality possessed by the berimbau as an instrument of violence in Bahian capoeira during the first decades of the twentieth century confirms the studies of this period in other regions of Brazil, which find capoeira practitioners occupying the crime pages of newspapers in Rio de Janeiro, Recife, Pará and so on. The berimbau's use as a fighting weapon in a context in which capoeira was associated with the population of African descent and, consequently, was being forcibly repressed as a practice, is barely visible in official documents. One of the rare reported incidents - compiled by historian Antonio Liberac Pires - dates from I9I8, in Santo Amaro, Bahia, and tells the story of Manoel Henrique Pereira (supposedly the real name of the famous capoeirista Besouro) who had been involved in an assault on police officers over a berimbau, "A badly-dressed individual appeared next to the central window of the police station, standing there for five minutes, just observing, after which the individual questioned the police officer, asking for the berimbau visible among the weapons that had been seized..." (apud Pires, 200I: 230). ${ }^{22}$

This case in mind, I argue that the berimbau constitutes an important object of agency for the capoeiristas, in the sense developed by Alfred Gell (I998: 7), operating, for example, as an acoustic locator of capoeira rodas for the police, as illustrated in one of the songs played with the berimbau in a capoeira roda: ${ }^{23}$ the cavalaria, or cavalry style, that was still being practiced in the academies of the I96os (Rego, I968: 63). The song mentions a general warning made forty years earlier, when the presence of the violent police officer Pedro de Azevedo Gordilho would require participants to prepare quickly for confrontation or escape - though, in both cases, the ritual would be performed by the instrument.

Another way through which the berimbau operates is visual: "They say Querido de Deus will fight today. I saw a group taking berimbaus that way" (Landes, 2002: 147). This is what Ruth Landes and Carneiro were told by a priest from an Afro-Brazilian religion on his way to one of the popular fairs in Salvador in 1938.

We also need to take into account that conditions for manufacturing the instrument, made from a specific kind of wood and steel wire taken from tyres, was very difficult (Biancardi, 2006: I I2). It was only from the second half 
of the twentieth century that production of berimbaus increased due to the higher demand generated by the expansion of capoeira groups and tourism. ${ }^{24}$ Prior to this time the relationship between a capoeira master and the berimbau had been more intimate and cautious. A popular verse sung in the Ig6os rodas recorded by Rego still perceives the berimbau's role in this way, calling it gunga, one of its many names: "Panhe esse gunga, me venda ou me dê/ Esse gunga não é meu, eu não posso vendê/ Panhe esse gunga, ou me venda ou me dê/ Esse gunga não é meu, e não posso vende" [Take that gunga and sell me or give me it/That gunga isn't mine, I can't sell it...] (I968: 53). The close friend of previous violent situations was still sung about as an object of use, locked in the universe of relations of exchange and circulation.

\section{ON THE BERIMBAU'S CORDIAL GINGA}

Quem, neste país, a esta altura do século, ainda não viu um berimbau?

[Who, in this country, at this point of the century, has yet to see a berimbau?] (Édison Carneiro, I975: I5).

The contrast with the decades after 1930 is considerable, a period when cultural issues assumed great importance in Brazilian government policies (Schwarcz, I995: 24) and Bahian capoeira became highlighted to the same degree as the actions implemented by the Vargas administration and the Folkloric Movement (Acuña, 2010; Reis, I993).

In fact, even the manuscript production of Mestres Noronha and Pastinha can be seen, I believe, as a negotiation on the part of members of the 'gingada city' in response to the intense changes implemented over the previous decades, which demanded the production of capoeira narratives in favour of the State, the tourist industry and the rapidly expanding capoeira academies. Records, books, movies, songs, paintings, photographs, performances and a whole series of other devices captured, elaborated and distributed accounts of capoeira and its practitioners at an industrial scale (Acuña, 2010).

A look at the ig6os, therefore, a moment when the aforementioned Mestres were writing their memoirs, reveals another configuration to the ways in which the berimbau was being used, suggesting a radical process of change involving members of the 'lettered city' and the 'gingada city.' This process tended to extol a notion of cordiality as a paradigm of Bahian capoeira, transforming this specific version of the practice and its ethics into a national model. In Mestre Pastinha's manuscripts we find a clue to this change:

... and capoeira has been unhappy when it was violent in the past, many teachers and others of us would draw a performer's attention when he wasn't keeping the rhythm, explaining politely, we educated people in the sport of capoeira, that's the reason why everyone trained in the past has good body movement and rhythm. The mas- 
ters keep secrets, but they never refuse to explain. You must sing the set lyrics and improvise too...25

Pastinha once again outlines the distinction between the old and violent capoeira and the more recent practices. But beside remarking on the decline in violence, he also emphasizes the role of the master in calling a disciple's attention when he fails to maintain the rhythm. He then immediately reminds them of the importance of the masters of the past, mentioning too the merging of body and rhythm, which, it seems, was absent from the performance of the capoeiristas who followed. This balance involved the development of blows and other physical movements, but also a strict control of the body under the sway of the berimbau's notes. The latter was "the primal master. It teaches through its sound. It gives vibration and ginga [swing] in our body" (Pastinha apud Abreu \& Castro, 2009: 28). ${ }^{26}$ This passage appears especially interesting because of the equivalence established between the instrument and the capoeira masters, expressed in the authority displayed by both and their combined capacity to instruct the capoeiristas.

Like body movements, rhythm is also a basic component for capoeiristas. Learning rhythm in the academies gave the berimbau the power to control the performers, which would be used by the masters as an important element in a set of practices that constituted a kind of 'disciplinary power,' albeit within a narrower framework. As Foucault sets out in Discipline and Punish, 'disciplines' should be understood as "methods, which made possible the meticulous control of the operations of the body, which assured the constant subjection of its forces and imposed upon them a relation of docility-utility" (Foucault, I995: 137).

Various examples of the changes taking place in capoeira may be seen from the perspective of operant techniques in the distribution of arts, the control of activities, the organization of geneses and the composition of forces. These, though, lie beyond the scope of the present article. ${ }^{27}$ Nonetheless, it is important to stress the effects of the 'political anatomy' that the berimbau enables within the two capoeira styles, such as the temporal elaboration of the performance and the correlation between body and gesture (2002: I5I), manifested in the vibration and swing of the performers' bodies. Even the differences between the Angolan and Regional styles can be conceived in terms of disciplinary power, noting their distinct emphases along the 'docility-utility' spectrum. Thus while the former accentuates docility, expressed in the malice that wavers between flight and confrontation, Regional capoeira heightens the senses in localized bodies and more widely coded activities.

The latter style provides an additional example. When Mestre Bimba claimed to have invented his Regional Capoeira, he did not cite just the distinct blows and body movements. He also emphasized its rhythm, the creation of a particular berimbau sound and a singular way of playing the instrument that later came to be recognized by many other capoeiristas. 
An interesting story concerning the creation of the new sound dates from 1936, the period when Bimba was trying to take capoeira to arenas in order to compete with other sports. Complaining about Angolan Capoeira's weakness as a sport, a practice that had previously taken players to Parque Odeon in Salvador, Bimba said that the problem was precisely the type of control exerted by the berimbau: "So, wherever I am, if attacked should I wait for the berimbau to react?" (apud Pires, 200I: 30I). ${ }^{28}$ Although the berimbau is depicted here as an obstacle to the practice's expression as a martial art, Mestre Bimba did not exclude it from the students' instruction, but changed its use to a more aggressive and specific capoeira sound than the kind usually taught. Muniz Sodré, a journalist and Bimba's disciple, offers a compelling story to contrast the two styles of capoeira, focusing on the musical dimension imprinted by the master when playing:

It needs to be remembered that capoeira is traditionally defensive [...]. That's why the Angolan style pulls back. What did Bimba do? By recreating blows and making movements more offensive, he pushed the style forward [...]. With Bimba, it became clear to me how the berimbau can increase the energy transmitted through the rhythm. The actions, the players' bodies and even the violence are strategically controlled by the berimbau... (Sodré, 2002: 82). ${ }^{29}$

It should be remembered that before the academies came into existence, the control of the body's movement and its submission to the music of the berimbau may have occurred in the numerous rodas held at popular fairs and festivals and recorded by intellectuals in the I930s and I940s. While the music was an important strategy in managing the violence present in capoeira, it also offered a sense of 'cordiality' that would be noticed and conceptualized by intellectuals as a brincadeira coletiva, or collective play (Carneiro, I955: 5I), a luta convertida em dança, fight turned into dance (Landes, 2002: I54), a diversão entre amigos, fun with friends (Carneiro, I937: I48), or vadiação, vagrancy (Robato, I954), among many other descriptions.

Bahian capoeira would seem to exemplify the kind of cordiality delineated by Sérgio Buarque de Holanda in his interpretation of the Brazilian personality, a practice that oscillates between affection and aggression, "legitimate expressions of an extremely rich and overwhelming emotional depth" (Holanda, I978: 107). ${ }^{30}$ Until the first three decades of the twentieth century, this oscillation could be observed in the relationship among capoeiristas themselves and also in their relationship with the forces of repression. In the following decades, however, apart from sporadic conflicts, I believe that the distinction between Angolan and Regional Capoeira provides a better representation of these oscillating poles of affection and aggression.

Just as the conduct of the homem cordial, the 'cordial man,' may differ from the impersonal and coercive foundations of civilized behaviour, Bahian capoeira also diverges from its conception as sport, the most common analogy made. Mes- 
tre Pastinha, the 'guardian' of Angolan Capoeira, asserted that he had 'civilized' capoeira (Acuña, 2010: I00), while the creator of Regional Capoeira, Mestre Bimba, said that he had included blows in order to make it more effective. Bahian capoeira during the period studied was often interpreted as a martial art disguised as a dance, or as dance that can, all of a sudden, turn into a bloody fight.

\section{FINAL NOTES: MPBERIMBAU}

Agora só se fala em berimbau Enquanto houver arame e um pedaço de pau Agora só se fala em berimbau. [Now people only talk about the berimbau While there's a wire and a piece of wood...] (Jackson do Pandeiro and Antonio Barros).

Some years ago the anthropologist Leticia Vidor Reis posed a controversial question: why has Bahian capoeira been raised to national status, rather than the capoeira from Rio de Janeiro, ${ }^{31}$ especially since carioca capoeira had been so popular and threatening in the nineteenth century (Reis, I993: I6)? According to the author, the reason may have been the Vargas administration's refusal to recognize a form of capoeira that maintained such close links to its murky past in the nineteenth century.

Putting aside this somewhat sweeping and unverifiable explanation, we can explore instead the more readily substantiated relationship between macro and micro politics, which allows us to trace the berimbau's agency beyond the capoeira rodas. Its central role in the disciplining of bodies parallels its inclusion in the universe of Brazilian Popular Music (MPB), ${ }^{32}$ literature, the visual art, periodicals and folklorist studies (Acuña, 20I0: I60). All of these contributed to the nationalization of the Bahian style of capoeira.

Taking just the musical dimension as an example, in the I96os we see the explosion of berimbau tones in what had become known as Brazilian Popular Music (Música Popular Brasileira: MPB). In I959, folklore studies described the instrument, attempting to delineate its shape and its uses. Yet it was only in the I960s that the instrument was depicted in more detail. A report from the Rio newspaper Correio de Manhã captures the new trend as follows:

The berimbau is here. In the wave of Bossa Nova that some people say is dying... Invading the halls, the scholarly and elegant dances... And alongside the traditional instruments - revived or invented for modern samba - the berimbau, or, as it was once called, the Urucungo, is being incorporated into orchestrations, adding a touch of primitivism to musical arrangements. It is being intellectualized... Despite its limited possibilities, whether played solo or accompanied, the truth is that suddenly, like capoeira, the public has acquired a taste for it and here it is. Showing what the fuss is about. ${ }^{33}$

As examples of this 'new fever,' the same feature mentions the LPs recorded by Bahian capoeira masters like Bimba, Traíra and Canjiquinha, as well as artists who had been using capoeira themes and sounds in their composi- 
tions, such as Vinícius de Moraes and Baden Powell with their samba 'Berimbau' (I963), or new musicians like Wanda Maria, who had recorded a song called 'Samba do berimbau.' The song 'Berimbau' (I963) introduces the musical rhythm of capoeira into the distinctive guitar arrangements of Bossa Nova, while song's verses mainly speak of the importance of love. A short time later, in I964, Vinícius returned to the theme in partnership with Antonio Carlos Jobim, recording the song 'Água de Beber.'

Finally, an another example is provided by Gilberto Gil in a song that became known throughout the country when he presented it at the $3^{\text {rd }}$ National Song Festival on TV Record in 1967:34 'Domingo no Parque.' This also adopts the musical rhythm of the berimbau while offering another form of integration by using the berimbau itself as an instrument in the song, which tells of the tragic fate of a love triangle. These are some examples of the berimbau's influence at the time, taken from different aspects of Brazilian music, and which demonstrate how Bahian capoeira, through the berimbau, spread at national level. ${ }^{35}$

The penetration of capoeira musical forms and songs in MPB becomes even more interesting when we consider, as Carlos Sandroni suggests, that the consolidation of the expression 'Brazilian Popular Music' took place during the I950s and I960s, just as a change was taking place in the very concept of 'the Brazilian people,' previously traced to folkloric manifestations in rural areas, but now being discovered in urban settings:

It was at this moment that enjoying MPB, recognizing oneself in MPB, also became a belief in a particular conception of 'the Brazilian people' and thus a particular conception of the country's republican ideals. As in previous decades, liking folklore and recognizing oneself in folklore - even at the cost of transfiguring the latter, as in the case of Villa-Lobos's music and Mário de Andrade's campaigning - meant believing in another version of who the people were (Sandroni, 2004: 29).

Amid the flux of this transforming concept of 'Brazilian people' in music, anchored in rural and later urban spaces, the berimbau chords - previously in tune with the image of Bahian capoeira (a fusion that had emerged and diffused over previous decades) - seemed to harmonize as point and counterpoint to the notes of a version of national identity popularized by the new audiences expanding through access to radio and television.

Even so, the berimbau never stopped playing with these new possibilities for negotiating between the music of capoeira and the wider cultural industry. In the I960s, in one of the many rodas in Salvador, another song could be heard: A coisa milhó do mundo/É se tocá berimbau/Lá no Rio de Janeiro/Na Rádio Nacional. The best thing in the world/Is to play berimbau/There in Rio de Janeiro/On the National Radio (Rego, I968: I06).

Received II/I4/20I5 | Approved 06/I0/2016 Translated by Ingrid Brioso Rieumont and Mauricio Acuña Revised by Benjamin Fogarty and David Rodgers 
Mauricio Acuña graduated in Social Sciences from the Universidade of São Paulo (USP) and obtained a MA in Social Anthropology from the same institution. His master's dissertation received IPHAN's Sílvio Romero award. He is currently a PhD candidate at Princeton University's Department of Spanish and Portuguese Languages and Cultures and in Social Anthropology at the Universidade de São Paulo. He is author of A ginga da nação: intelectuais na capoeira e capoeiristas intelectuais (2015). 


\section{NOTES}

I Mestre (Master) Pastinha, seen as the guardian of the 'Capoeira Angola' tradition, visited Dakar in I966 as a member of the Brazilian delegation that attended the First World Festival of Black Arts, promoted, among others, by Léopold Senghor, Aimé Césaire and Alioune Diop, three leading intellectuals from the movement known as 'Négritude.' Caetano Veloso's song was released in 1972 on the album Transa issued by the Polygram label.

2 Several studies have been devoted to analysing the globalization of capoeira, a process that began in the midI96os with tours of Brazilian folkloric groups in Europe and the United States, and then became consolidated with an extensive migration of capoeiristas to North America and Europe in the I980s and I990s. See Barros de Castro (2007) and Travassos (2000).

3 Albano Neves e Sousa was an Angolan painter who in I966 held an exhibition entitled Da minha África e do Brasil que eu vi (About my Africa and the Brazil that I saw) recalling his travels to Portuguese-speaking countries. From his trip to Brazil, we find his description of the N'Golo or zebra dance, a ritual practiced by certain groups in the region today forming part of Angola, and which is considered an ancestor to capoeira. This idea would be promoted later by the writings of Câmara Cascudo in books such as Folclore do Brasil (1967). See Assunção \& Cobra Mansa (2008).

4 The terms 'practice,' 'dance,' 'fight' or 'play,' as well as 'strike,' 'blow' and 'movement,' are all used varyingly to capture the shifting and ambiguous meanings of capoeira. As I propose in this text, the diverse use of these words form part of a rhetoric that assumes the instability of the practice in different contexts and should not be understood as static and immutable concepts.

5 According to the Angolan painter Albano Neves e Souza, N'Golo, or the Zebra Dance, is performed by young men in the Mucope and Mulondo regions when they reach puberty: "the aim of the dance is to strike your opponent's face with your foot. The dance rhythm is marked by clapping hands and anyone who attempts to land a blow while outside the arena is disqualified..." (apud Assunção, 2005: 49). 
6 The full video can be seen at: https://www.youtube.com/ watch $? \mathrm{v}=2 \mathrm{QNoz} P l N B H Y \&$ inde $\mathrm{x}=9$ \&list $=\mathrm{PL}_{3} \mathrm{SjG}_{3} \mathrm{X}_{-} \mathrm{xH}$ 6 6 eJi8ux5jilSoSGU22QcF. Accessed May 2016.

7 A list of capoeira groups around the world can be found on the Itamaraty (Brazilian Foreign Office) website: http:// www.brasileirosnomundo.itamaraty.gov.br/a-comunidade/ associacoes-de-capoeira-no-mundo. Accessed June 2016.

8 According to the descriptions given by Manuel Quirino in I9I6 (I922), followed among others by Carneiro (I937) and Waldeloir Rego (I968), the instrumental ensemble responsible for playing capoeira music in Bahia took on a variety of formats throughout the twentieth century, but always with the berimbau featuring as a central and invariable element. Since the ig6os the musical ensemble of the Angolan Capoeira has assumed the format of three berimbaus, each with different sized gourds (which emit different tones when played), two tambourines, one agogô, one recoreco and one pandeiro (another kind of tambourine). The Regional Capoeira style typically uses the same structure but may also employ a more simplified set of just two berimbaus and one pandeiro. In both cases the Regional style still includes rhythmical clapping as accompaniment to the ensemble (Acuña, 2010; Sousa, 2008).

9 I use the expression 'gingada city' by way of analogy with Ángel Rama's notion of the 'lettered city' (I988). The concept of the 'gingada city' allows us to foreground other forms of organizing knowledge and powers in a given urban space, operating in relation to the 'lettered city' but displaced or subordinated by the latter's centrality and hegemony.

Io The discourse generated by works such as Gilberto Freyre The Masters and the Slaves and Sérgio Buarque de Holanda's Roots of Brazil, as well as from cultural institutions at state and federal levels, has played a significant role in shaping the image of the mestizo, which "arises in this way, constantly reinvested as the ambiguity of space, the support of representations" (Schwarcz, I995: 27).

I I Less well-known than Bimba and Pastinha, Daniel Coutinho - Mestre Noronha - was born in I909 in Salvador, Bahia. A contemporary of the two other masters, he is cited by Pastinha as one of the members of the Gengibirra roda 
that performed in the early i940s and was trained by some of the great masters. In 1993, the researcher Frede Abreu published a set of manuscripts written by Coutinho throughout his life, revealing important aspects of the capoeira universe during the first half of the twentieth century (Coutinho, I993).

I2 "Sinhores capoerista e profesor de cademia preste bem atenção o birinbão é um itrumento que dirige a roda de capoeira... Sinhores profesor este itrumento que cichama birinbão é uma arma do capoerista nais hora nececaria para barulho a sua defeiza está em sua mão não são todos capoerista que sabe desta definição que o birinbão é uma arma a verga é um cacete para defender e dar a vaqueta é para furar e si defender do inimigo esta instrucão é dos velhos metres que sabe entra e sair de um barulho" (Coutinho, I993: 29).

I3 Or so we can assume from the dates attributed to some of the events mentioned in the manuscripts.

I4 Dias informs us that in conflicts involving capoeiristas between I9Io and 1925, " $49 \%$ of the weapons used by our people were knives and different types of knife" (Dias, 2005: 280, note 25).

I5 The same author mentions that "Drinking sprees in bars, loose behaviour with prostitutes, gambling and fights with the police were commonplace in the lives of seamen and capoeiristas alike" (Dias, 2006: 282).

I6 "Para que serve o berimbau? Não é só para indicar o jogo. $\mathrm{E}$, porque o birinbau na hora $\mathrm{H}$. é pirigouso? É pirigoiso nas mãos de quem sabe maneijar o birimbau, ou coisa semelante" (I997: 53).

I7 "Berimbau é música, instrumento... também é instrumento ofensivo. Ele na ocasião de alegria é um instrumento, nós usamo como instrumento, e na hora da dor ele deixa de ser instrumento para ser uma foice de mão..." (Pastinha, I969: track 3).

I8 "Eu vô contá, no meu tempo eu usava também uma foicezinha do tamanho de uma chave, a foice vinha com um corte e um anel para encaixar no cabo... e aí na hora desmanchava o berimbau, encaixava a foice e eu ia manejá, né...?" (Pastinha, I969: track I). 
I9 Once again in Dias we find the following observation: "In reality, there is no doubt that capoeira was repressed. It was not absolute, though, and there were ways to get round it, mainly through bribery and personal relations" (Dias, 2006: 303).

$20 \mathrm{He}$ was not alone in this view. Note what Master Noronha states: "so acin esta festa de Santa Luzia tinha suceigo por que a policia tomou muita precação. Aradecemos au nosco chefe de polícia do Estado da Bahia..." [only because of this [police action] did this Santa Luzia festival take place peacefully. We are thankful to our Bahia State police chief...] (Coutinho, 1993: 37).

2I “[...] porque si estava numa vadiação ni um grupo, com um birimbao... na mão, eles passava entendia de quere tomá, pá quebrá, aí inflamava né, por isso tinha muito capoeirista que não queria perder seu instrumento, intão nós tinhamo que briga..." (Pastinha, I969: track 3).

22 "Ali compareceu um indivíduo mal trajado, e encostandose à janela central do referido posto, durante uns cinco minutos, em atitude de quem observava alguma coisa; que decorrido este tempo, o dito indivíduo interpelando o respondente, pediu-lhe um berimbau que se achava exposto juntamente com armas apreendidas..." (apud Pires, 200I: 230).

23 The berimbau toques, or playing styles, can vary from master to master. Waldeloir Rego noted that, amid all the variety, the following toques were more common among the capoeiristas of Salvador: Angola, São Bento Grande, São Bento Pequeno, Cavalaria, Iuna and Benguela (Ig68: 62).

24 As we lack absolute figures, a good example might be the case of Mestre Waldemar da Paixão, who led an important capoeira group between the I940s and I970s and was an expert in producing berimbaus, as well as being widely admired for his wood panel paintings (Biancardi, 2006: II7).

25 “[...] e a capoeira vem amofinando-se quando no passado ela era violenta, muitos mestres, e outros nos chamavam tensão, quando não estava no ritimo, esplicava com decencia, e davanos educação dentro do esporte da capoeira, esta é a razão que todos que vieram do passado tem jogo de corpo e ritimo. Os mestres rezerva segredos, mais 
não nega a esplicação. Você deve cantar com inredo e improvisado..." (Decânio, I997: 30).

26 “O primitivo mestre. Ensina pelo som. Dá vibração e ginga no corpo da gente."

27 Although some works on the history of capoeira in the twentieth century emphasize the differences between the Angolan and Regional styles - linking the latter with the adoption of principles such as utility and efficiency, thereby supposedly rationalizing and bureaucratizing the practice (Vieira, I995) or 'whitening' it (Frigerio, I989; Reis, I997) - it is important to stress that Angolan capoeira also incorporates these values (Acuña, 2010).

28 "Pois então, em qualquer lugar, sou atacado e vou esperar pelo berimbao para reagir?"

29 “...é preciso levar em conta que o jogo da capoeira é tradicionalmente defensivo [...]. Por esse motivo, o toque angola puxa para trás. Que fez Bimba? Recriando golpes e tornando mais ofensiva a movimentação, puxou o toque para frente [...]. Com Bimba, tornou-se claro para mim como pode o berimbau aumentar a energia que passa no ritmo. o jogo, os corpos dos jogadores e, eventualmente, a violência são estrategicamente controlados pelo berimbau..." (Sodré, 2002: 82).

30 "...expressões legítimas de um fundo emotivo extremamente rico e transbordante."

3I Reflecting on samba and capoeira together, the researcher states that a form of inversion occurred at the beginning of the century with the nationalization of the samba from Rio de Janeiro and, later, Bahian capoeira (Reis I993: I6).

32 Here I use the notion of MPB in a sense equivalent to the historical process indicated by Sandroni (2004: 29): "Indeed, over the course of the I96os, the words Brazilian Popular Music, always used together as though written with hyphens, started to designate unequivocally the urban music broadcast on the radio and on LP records [...]. The concept of a 'Brazilian-Popular-Music,' ideologically branded and crystallized in the acronym 'MPB,' is linked, in my view, to a moment in the history of the Republic in which the idea of a 'Brazilian people' - a people, it was believed, who were increasingly urban - is central to many debates and where the role played by music was far from minor". 
33 "Na onda do berimbau" [In the wake of the berimbau]. Fuad Atala's feature article in the Correio de Manhã, Rio de Janeiro, October 18, I964. Cultura-diversão, p. 8.

34 The song, won second place at the festival, would be rerecorded numerous times by other artists such as $\mathrm{Gal}$ Costa, Golden Boys, Hermeto Pascoal, Margareth Menezes, Os Mutantes, Rita Lee, Rogério Duprat, Duofel and others. Information obtained from the official website of Gilberto Gil. Available at: http://www.gilbertogil.com.br/ sec_musica.php?page=2. Accessed June 2016 .

35 Waldeloir Rego (I968: 332-35I) provides a long list of songs that incorporate the berimbau and capoeira songs as themes.

\section{BIBLIOGRAPHY}

Abreu, Frede \& Barros de Castro, Maurício (eds.). (2009). Coleção Encontros - Capoeira. São Paulo: Azougue.

Acuña, Jorge Mauricio Herrera. (2010). Entre rodas de capoeira e círculos intelectuais: disputas pelo significado da capoeira no Brasil (I930-I960). Master's Dissertation. PPGAS/ Universidade de São Paulo.

Anderson, Benedict. (1983). Comunidades imaginadas. Reflexões sobre a origem e a expansão do nacionalismo. Lisbon: Edições 70.

Albuquerque, Wlamyra. (I999). Algazarra nas ruas. Comemorações da independência na Bahia (1889-I923). Coleção Várias Histórias. Campinas: Ed. Unicamp.

Assunção, Matthias Röhrig e Cobra Mansa, Mestre. (2008). Elo Perdido. Seria o n'golo, jogo ritual praticado em Angola, o ancestral da nossa capoeira? Available at: <http:// www.revistadehistoria.com.br/secao/artigos/elo-perdido>. Accessed I3 may 2015.

Bhabha, Homi. (2007). Compromisso com a teoria. In: O local da cultura. Belo Horizonte: Ed. UFMG.

Biancardi, Emilia. (2006). Raízes musicais da Bahia. Salvador: Omar G.

Carneiro, Édison. (1937). Negros Bantus. Rio de Janeiro: Civilização Brasileira. 
Carneiro, Édison (1955). Pesquisa de Folclore. Rio de Janeiro: Instituto Brasileiro de Educação e Cultura/ Comissão Nacional de Folclore.

Carneiro, Édison (1975). Capoeira. Rio de Janeiro: Campanha de Defesa do Folclore Brasileiro.

Coutinho, Daniel. (1993). O ABC da capoeira Angola. Os manuscritos de Mestre Noronha. Brasília: Defer.

Dantas, Beatriz G. (I988). Vovó nagô, papai branco. Rio de Janeiro: Graal.

Dias, Adriana Albert. (2006). Mandinga, manha e malícia: uma história sobre os capoeiras na capital da Bahia (I9Io-I925). Salvador: EDUFBA.

Foucault, Michael. (1995). Discipline and punish: the birth of the prison. New York: Vintage Books.

Frigerio, Alejandro. (1989). Capoeira: de arte negra a esporte branco. Revista Brasileira de Ciências Sociais, Io/4, p. 85-98.

Gell, Alfred. (1998). Art and agency. London: Clarendon Press.

Hall, Stuart. (2003). A identidade cultural na pós-modernidade. $7^{\text {th }}$ ed. São Paulo: DP\&A.

Holanda, Sérgio Buarque de. (I978). Raízes do Brasil. Rio de Janeiro: José Olympio.

Landes, Ruth. (2002). A cidade das mulheres. $2^{\text {nd }}$ ed. rev. Rio de Janeiro: Ed. UFRJ.

Thomas, Nicholas. (1998). Foreword. In: Gell, Alfred. Art and agency. London: Clarendon Press.

Oliveira, Josivaldo Pires de. (2004). Pelas ruas da Bahia: Criminalidade e poder no universo dos capoeiras na Salvador Republicana (I9I2-I937). Master's Dissertation. Programa de Pós-Graduação em História/Universidade Federal da Bahia.

Pires, Antonio Liberac Cardoso Simões. (200I). Movimentos da cultura afro-brasileira - A formação histórica da capoeira contemporânea (I890-I950). Doctoral Thesis. Programa de Pós-Graduação em História/Unicamp.

Querino, Manuel. (1922). A Bahia de outrora. Salvador: Livraria Econômica. 
Decânio, Angelo. (1997). A herança de Pastinha. Coleção São Salomão. Salvador: n/ed.

Rama, Angel. (I998). La ciudad letrada. Montevidéu: ARCA. Rego, Waldeloir. (I968). Capoeira Angola: Ensaio sócio-etnográfico. Salvador: Editora Itapuã.

Reis, Letícia Vidor. (1997). O mundo de pernas para o ar: a capoeira no Brasil. São Paulo: Publisher Brasil.

Reis, Letícia Vidor. (I993). A "Aquarela do Brasil": reflexões preliminares sobre a construção nacional do samba e da capoeira. Cadernos de Campo. Revista dos Alunos de Pós-Graduação em Antropologia Social da Universidade de São Paulo, 3, p. 5-19.

Rohrig, Mathias. (2005). Capoeira. The history of an Afro-Brazilian martial art. London: Routledge.

Sandroni, Carlos. (2004). Adeus à MPB. In: Cavalcante, Berenice; Starling, Heloísa; Eisenberg, José (eds.). Decantando a República: inventário histórico e político da canção popular moderna brasileira. Rio de Janeiro/São Paulo: Nova Fronteira/Fundação Perseu Abramo (vol. I).

Schwarcz, Lilia Katri Moritz. (I995). Complexo de Zé Carioca. Sobre uma certa ordem da mestiçagem e da malandragem. Revista Brasileira de Ciências Sociais, 29/ıo, p. I7-30. Shaffer, Kay. (1977). O berimbau de barriga e seus toques. Rio de Janeiro: Ministério da Educação e Cultura.

Silva, Roque \& Albano, Manuel. (2013). Grande homenagem ao Mestre Kamosso. Available at: <http://jornaldeangola. sapo.ao/cultura/musica/grande_homenagem_ao_mestre_kamosso>. Accessed 6 nov. 2015.

Sodré, Muniz. (2002). Mestre Bimba: corpo de mandinga. Rio de Janeiro: Manati.

Vilhena, Luis Rodolfo. (I997). Projeto e missão. O Movimen to Folclórico Brasileiro (I947-I964). Rio de Janeiro: Funarte/ Ed. FGV.

Sousa, Ricardo Pamfilio de. A música na capoeira Angola da Bahia. In: Departamento Cultura, Ministério das Relações Exteriores. Textos do Brasil - Edição número I4. Available at: <http://dc.itamaraty.gov.br/imagens-e-textos/ revista-textos-do-brasil/portugues/edicao-no-I4-capoeira>. Accessed 3I May 2016. 
404

Travassos, Sônia Duarte. (2000). Capoeira: difusão e metamorfose culturais entre Brasil e EUA. Doctoral Thesis. Departamento de Antropologia do Museu Nacional/ Universidade Federal do Rio de Janeiro.

Vieira, Luís Renato. (I995). O jogo da capoeira: corpo e cultura popular no Brasil. Rio de Janeiro: Sprint.

\section{MUSIC}

Capoeira Angola - Mestre Pastinha e sua Academia. Rio de Janeiro: Polygram, I968.

\section{FILM}

Vadiação. Directed by Alexandre Robatto Filho. São Paulo, I954. 


\section{Palavras-chave \\ Berimbau; \\ Agência;}

Comunidade imaginada;

Corpo;

Capoeira.

Keywords

Berimbau;

Agency;

Imagined community;

Body;

Capoeira

\section{A GINGA SOCIAL DO BERIMBAU: NOTAS PARA COMPREENSÃO DA AGÊNCIA NA CAPOEIRA}

\section{Resumo}

Embora o berimbau seja consensualmente reconhecido como parte inseparável da capoeira praticada hoje em diferentes países, a história desse instrumento tem minimizado sua relevância diante de seus devires ao longo do século XX. Os sons, canções, toques do berimbau e sua circulação entre capoeiristas, artistas, esportistas e intelectuais foram fundamentais na passagem de uma capoeira baiana "venenosa" para os estilos "sem veneno". Tais estilos se nacionalizaram com suficiente malícia para garantir a ambivalência entre luta, jogo e dança que a capoeira fez repercutir e reiterou entre os anos I930 e I960. Estas notas abordam o objeto berimbau como dotado de um tipo de agência específica para a imaginação nacional da capoeira, assim como para o controle dos corpos e hierarquias entre seus praticantes.

\section{THE BERIMBAU'S SOCIAL GINGA: NOTES TOWARDS} A COMPREHENSION OF AGENCY IN CAPOEIRA

Abstract

Although the berimbau is widely acknowledged today as part of capoeira - in Brazil and around the world - only a 'minimal' history of this instrument exists concerning its evolution over the twentieth century. The sounds, songs and notes of the berimbau, as well as its circulation among capoeiristas, artists, athletes and intellectuals, played an important role in the historical shift from a 'poisonous' capoeira to the 'non-poisonous' styles. The latter were the same styles that became national with enough of a violent edge to maintain the ambivalence between martial art, game and dance, as exemplified and echoed by the capoeira movement between I930 and I960. This article approaches the berimbau as an object embodied with a specific kind of agency, useful to the national imagination, to the control of the body and to the promotion of hierarchies among its practitioners. 